\title{
ABORIGINAL IMPACT AND BENEFIT AGREEMENTS: Practical Considerations
}

\author{
SANDRA GoGal," RICHARd RIEGERT“" and JOANN JAMIESON “.
}

Resource development on Aboriginal lands requires consultation with Aboriginal peoples and subsequently the negotiation of Impact Benefit Agreements (IBAs). Case law in the area is rapidly emerging and standards for indusiry have been increased. Similarly, the application of land claim agreements, agreements in principle and a variety of provincial and federal legislation creates a complex web of considerations for negotiating IBAs.

Drawing on industry experience and existing jurisprudence, what follows is an explanation of: why IBAs need to be negotiated by developers: informalion on key and contentious elements; critical planning considerattons; and guidance for navigating this complex and uncersain territory with a view to creating mutually beneficial commercial relationships.

\begin{abstract}
La mise en valeur de ressources sur des terres autochtones exige la consultation des peuples autochtones puis la négociation d'une Entente sur les répercussions el les avamages. la jurisprudence dans ce domaine évolue rapidement et les normes de l'indusirie ont été rehaussées. De mème, les accords sur les revendications territoriales, les ententes de principe et nombre de lois provinciales et fédérales créent un réseau complexe de considérations pour la négociation d'une telle Entente.

$S$ 'inspirant de l'expérience de l'industrie el de la jurisprudence existante, ce quisuil est une explication de la raison pour laquelle les promoteurs de projet doivent négocier les Ententes sur les répercussions et les avantages et des considérations de planification crifigue. L'article donne aussi une orientation pour naviguer sur ce territoire complexe et incertain dans le but de nouer des relations commerciales mutuellement bénéfiques.
\end{abstract}

\section{TABLE OF CONTENTS}

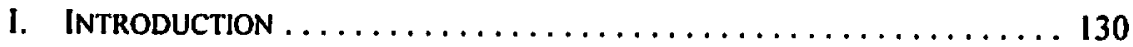

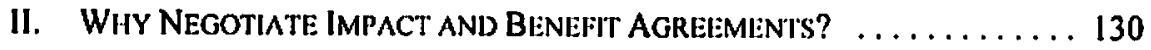

A. COMMON LAW DUTY TO CONSULT AND

SECTION 35 OF THE CONSTITUTION ACT, $1982 \ldots \ldots \ldots \ldots \ldots .130$

B. STATUTORY REQUIREMENTS $\ldots \ldots \ldots \ldots \ldots \ldots \ldots \ldots \ldots \ldots \ldots \ldots$

C. REgulatory REQuiREMENTS $\ldots \ldots \ldots \ldots \ldots \ldots \ldots \ldots \ldots \ldots$

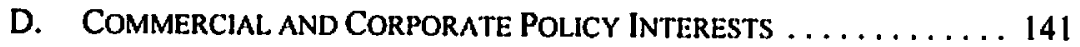

III. Project Planning Considerations $\ldots \ldots \ldots \ldots \ldots \ldots \ldots \ldots, \ldots \ldots$

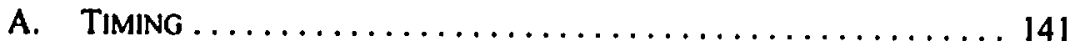

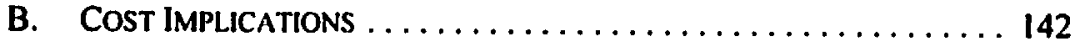

IV. Negotiating IMPACt BEnEFIt AGREements $\ldots \ldots \ldots \ldots \ldots \ldots \ldots, 143$

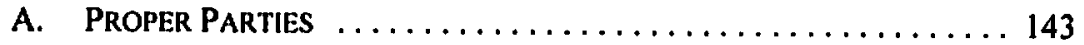

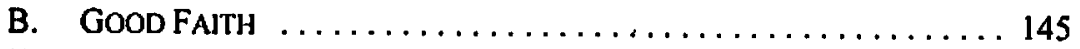

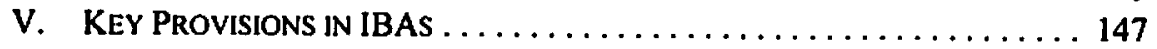

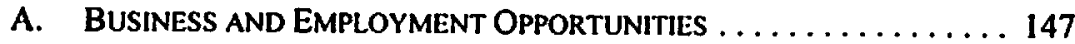

B. CaPaCITY BUILDING $\ldots \ldots \ldots \ldots \ldots \ldots \ldots \ldots \ldots \ldots \ldots \ldots$

C. Financial. Provisions $\ldots \ldots \ldots \ldots \ldots \ldots \ldots \ldots \ldots \ldots \ldots \ldots \ldots \ldots$

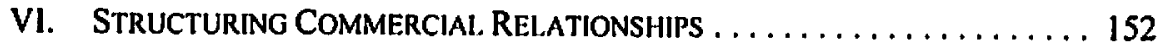

A. Aboriginal. Perspective on Participation $\ldots \ldots \ldots \ldots \ldots, 152$ 
B. INDUSTRY PERSPECTIVE ON PARTICIPATION $\ldots \ldots \ldots \ldots \ldots \ldots$

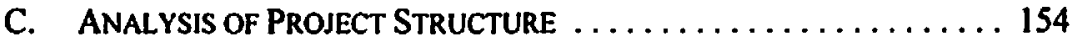

D. VARIATIONS OF PARTICIPATION StrUCTURES $\ldots \ldots \ldots \ldots \ldots .155$

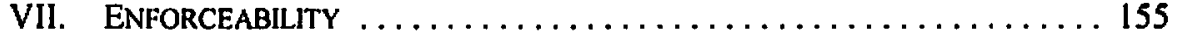

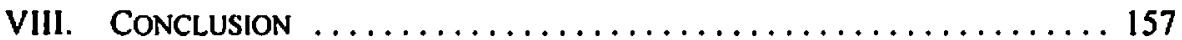

\section{INTRODUCTION}

One of the biggest challenges for any resource developer is to understand and meet its obligations towards Aboriginal peoples prior to and during the life of a project. Before any development proceeds, a number of legal and regulatory requirements must be met. Where the project is contemplated on Aboriginal lands, additional considerations, including the negotiation of an Impact and Benefit Agreement (IBA), may be required.

The purpose of this article is to put into context why developers negotiate IBAs, to identify what needs to be considered during project planning and IBA negotiations, and to discuss some of the key and often contentious provisions contained in IBAs. The article also attempts to give industry a sense of what can be anticipated by way of Aboriginal expectations during IBA negotiations and how legal risks can be minimized. Finally, some thoughts on how to structure commercial relationships with Aboriginal communities are provided.

\section{WHY NEGOTIATE IMPACT AND BENEFIT AGREEMENTS?}

There is no single legal and policy framework that applies to the negotiation of IBAs. The legal requirement for IBAs principally come from three sources:

(1) the common law duty to consult and s. 35 of the Constitution Act, $19822^{2}$

(2) statutory requirements, including land claim or settlement agreements; and

(3) regulatory requirements.

\section{A. Common Law Duty to Consult and}

SECTION 35 OF THE. CONSTITUTION ACT, 1982

Depending on the status of the Aboriginal land claim in the area proposed for development, a requirement to negotiate IBAs may stem from the common law duty to consult Aboriginal peoples. This common law duty stems from the Crown's fiduciary obligation towards Aboriginal peoples and s. 35 of the Constitution Act, 1982, which are interrelated.

Section $35(1)$ of the Constitution Act, 1982 protects existing Aboriginal and treaty rights:

I For the purpose of this article we have used the term IBA to encompass participation agreements, cooperation agreements, benefit plans, memorandum of understandings and any other form of agreement with Aboriginal communities dealing with benefits.

Being Schedule B 10 the Canada Act 1982 (U.K.). 1982. c. II [Constitution Act]. 
The existing aboriginal and treaty rights of the aboriginal pcoples of Canada and hereby recognized and affirmed.

The words "recognition" and "affirm" contained in s. 35(1) incorporate the fiduciary relationship between the Crown and Aboriginal peoples and necessarily imply some restraint in the exercise of sovereign power. ${ }^{3}$

While Aboriginal rights are recognized and affirmed, they are not absolute. ${ }^{4}$ Aboriginal rights may be infringed if legislatures can satisfy the justification test established in Sparrow. Briefly, if proposed legislation has the effect of interfering with an existing Aboriginal right, it results in a prima facie infringement of rights protected under s. 35(1) and the onus shifts to the Crown to demonstrate that the infringement is justified. ${ }^{3}$ In order to justify the infringement, the Crown must demonstrate the offending legislation has a valid legislative objective. If the objective is valid, the infringement must be justified in the context of the Crown's fiduciary role towards Aboriginal peoples. While somewhat ambiguous, the Court in Sparrow indicates the following questions will assist in determining this:

1. whether there is as little infringement as possible in order to effect the desired result;

2. whether priority in the allocation of the right has been given to the Aboriginal group;

3. where expropriation occurs, fair compensation is available; and

4. whether the Aboriginal group concerned has been consulted with respect to conservation measures. ${ }^{\circ}$

It is from this perspective that the duty of consultation arises as part of the Crown's fiduciary obligation to protect Aboriginal rights where they are likely to be infringed. This principle was later reaffirmed by the Supreme Court of Canada in the decision of Delgamuukw v. British Columbia:

Whether the aboriginal group has been consulted is relevant to determining whether the infringement of aboriginal title is justified, in the same way that the Crown's failure to consult an aboriginal group with respect to the terms by which reserve land is leased may breach its fiduciary duty al common law: Guerin. ${ }^{7}$

\section{ABORIGINAL RightS AND SCOPE of CONSULtTATION}

Any development of resources on Aboriginal lands has the potential to infringe Aboriginal rights. As part of the consultation process, there is an obligation on the Crown to assess the nature of the Aboriginal rights at issue. ${ }^{8}$ Aboriginal rights that are recognized and affirmed

R. v. Sparrow, [1990] I S.C.R. 1075 at 1108 [Sparrow].

lbid at 1109.

Ibid.

Ibid. at II 19 [emphasis added].

[1997] 3 S.C.R. 1010 at para. 168 [Delgamuskw], referring to a principle oullined in Guerin v. Canada. [1984] 2 S.C.R. 335.

Kelly Lake Cree Nation v. British Columbia (Minster of Energy and Mines). [1999] 3 C.N.L.R. 126

at 158 (B.C.S.C.) [Kelly Lake]. 
by s. 35(1) fall along a spectrum with respect to their degree of connection with the land. ${ }^{9}$ At one end of the spectrum are practices, customs and traditions that are integral to the distinctive Aboriginal culture of the group claiming the right, such as religious ceremonies, language and dialect. Treaty and "site specific" rights that are dependent on the use of the land, such as harvesting, fishing and trapping, are somewhere in the middle. Aboriginal title, being an indefeasible-like interest in land, is at the other end of the spectrum. ${ }^{10}$

It is along this spectrum of Aboriginal rights that one can assess the degree of consultation required. The greater the Aboriginal right impacted by a development, the more significant consultation will be.

In the context of Aboriginal title, Delgamuukw elaborated on the scope of consultation required:

In occasional cases, when the breach is less serious or relatively minor, it will be no more than a duty to discuss important decisions that will be taken with respect to lands held pursuant to aboriginal title. Of course, even in these rare cases when the minimum acceptable standard is consultation, this consultation must be in good faith, and with the intention of substantially addressing the concems of the aboriginal peoples whose lands are at issue. In most cases, it will be significantly deeper than mere consultation. Some cases may even require the full consent of an aboriginal nation, particularly when provinces enact hunting and fishing regulations in relation to aboriginal lands.

[A]boriginal title, unlike the aboriginal right to fish for food, has an inescapably economic aspect ... [whiclı] suggests that compensation is relevant to the question of justification."

The exclusive nature of Aboriginal title may suggest accommodating the participation of the Aboriginal group in the development of the resources and decision making.

The following table is a useful illustration of the principles set out in Delgamuukw:

TABLE 1

ABORIGINAL RughtS

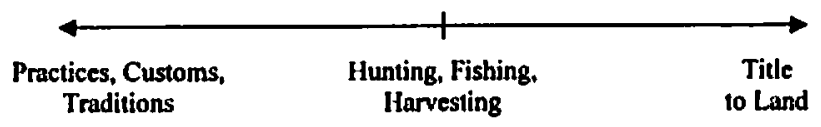

Consultation

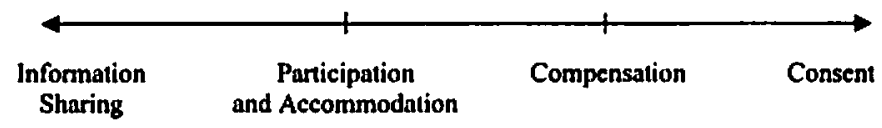

Sparrow, supra note 3 at 1094 .

Ibid.

Supra note 7 at para. 168. 
In practical terms, consultation will include, at a minimum, providing technical information about the proposed development, including feasibility studies, to enable Aboriginal peoples to determine whether the development, as contemplated, will impact their rights. In addition to accommodating the participation of the Aboriginal group in the development and decision making, accommodation and participation can include participating in the design and conduct of environmental and engineering studies and providing other benefits, such as employment and business opportunities and other initiatives aimed at building capacity. If a project has serious impacts, compensation may also be appropriate and may include direct or indirect financial payments or profit-sharing arrangements. This component will be discussed in more detail later in this article.

Of critical importance to developers is the Supreme Court of Canada decision in Haida Nation v. British Columbia (Minister of Forests), ${ }^{12}$ which ended the legal uncertainty as to where the duty to consult lies. The Supreme Court has ruled that the legal duty to consult Aboriginal peoples with respect to decisions that may affect potential Aboriginal rights which have yet been proven lies with the Crown and not industry. The Court reaffirmed the principle set forth in Delgamuukw $w^{13}$ that consultation does not require an agreement to be reached but it does require good faith efforts to understand each others' concerns and move to address them.

The Court further held that resource developers do not owe an independent duty to consult with or accommodate. The duty derives from the honour of the Crown and it cannot be delegated. However, the writers caution developers as to a number of potential issues that could arise. Should the Crown fail to consult or fail to consult adequately, developers risk having their permits revoked or suspended until such time as the Crown fulfills its legal obligations. In practical terms, developers will need to be intimately involved in the process in order to ensure the interests of Aboriginal peoples are appropriately challenged. In reality, developers will likely be required to conduct the consultation as they are more knowledgeable of the project and its impacts as well as being in the financial position to offer mitigation and other benefits.

\section{RELATIONSHIP BETWEEN CONSULTATION AND IBAS}

The results of the consultation between a developer and the impacted Aboriginal community are typically captured in an IBA, which will outline the impacts of the project and benefits provided, including financial compensation. In essence, the IBA contains the terms and conditions on which the development may proceed on the lands claimed by Aboriginal peoples.

\section{a. Duty to Consult in Labrador - An Example}

By virtue of the current status of Aboriginal land claims in the Province of Newfoundland and Labrador, Labrador is a good example of where IBAs are negotiated as the result of the common law or constitutional duty to consult. There are three Aboriginal groups in Labrador 
that claim Aboriginal rights and title: the Innu and the Métis, who do not have settled treaties or land claim agreements in Labrador; and the Inuit, who recently had their Land Claim Agreement ratified and passed by government.

\section{INUIT}

With respect to the Inuit, the Land Claim Agreement gives the Inuit 28,000 square miles of land in the Settlement Area and 17,000 square miles of adjacent ocean extending out 12 miles (the Zone). Before any decision is made to open up the Zone to petroleum exploration, to issue petroleum interests, to permit, license or grant the right to construct, operate or abandon a pipeline, to establish terms of references for public review of a petroleum development or environmental assessment or to decide whether to approve a development plan for a petroleum development in the Zone, the Regulator is required to consult the Inuit Central Government. In addition to the foregoing, no "Major Development,"14 or any part, phase or stage of a Major Development, may commence in the Zone until an agreement has been concluded or otherwise established between the developer and the Inuit Central Government.

Matters for inclusion in the agreement or IBA are set out in Schedule 6A and include the following:

1. Preferential employment and training of Inuit;

2. Inuit involvement in management of the Major Development;

3. Joint venture arrangements or other business arrangements between Inuit businesses and the Developer;

4. Inuit participation in corporate ownership:

5. Income sharing arrangements between the Developer and the Inuit:

6. Employment conditions that are consistent with Inuit values and culture;

7. Language in the workplace;

8. Researcl;;

9. Scholarships;

10. Relationship with unions;

11. Compensation;

12. Performance bonds;

13. Special concerns relating to environmental prolection, wildlife, habitat, fish and fish habitat and any disruption to the environment, wildlife, habitat, fish or lish habilat;

14. Inuit social and cultural protection, including protection of archeological material and archeological sites. ${ }^{15}$

it "Major Development" is defined as a development within the Labrador Sctllement Area that involves during any five year period cither more than 150 person ycars of employment or capital expenditures of more than $\$ 40$ million in constant 1998 dollars. "Development" is defined to include a commercial or industrial undertaking excluding exploration, map staking and National Parks or National Park Reserves.

is Agreemen in Principle, benween the Inuit of Labrador, Government of Newfoundland and Labrador and Government of Canada (10 May 1994), online: Government of Newfoundland and Labrador <www.gov.nf.ca/laa/claimsaip/Aipchp6.htm> [Labrador Imuit AIP]. 
Developers who wish to proceed with any project in Labrador on Inuit lands will need to comply with the substantive and procedural elements contained in the Land Claim Agreement.

\section{INNU}

The Innu people of Labrador also claim Aboriginal rights and title to the land and resources in Labrador. While their land claim has not been settled, it has been accepted for negotiation by the Government of Canada and the Government of Newfoundland and Labrador, which is sufficient, in the author's opinion, to warrant consultation.

However, in the absence of a settled land claim, it is difficult to ascertain with certainty the depth of their Aboriginal interests, ${ }^{16}$ and the scope of consultation will depend on the developer's assessment of the strength of the land claim and the degree of impact the project will likely have.

\section{MÉTIS}

In 2004, the Supreme Court of Canada in $R$. v. Powley ${ }^{17}$ recognized the Métis' claim for Aboriginal rights and title, provided the group claiming such rights can meet the test set out therein. Whether the Métis in Labrador can meet the test set out in the Powley decision to trigger the duty to consult and negotiate IBAs is beyond the scope of this article. For now, a developer will need to review the evidence establishing such rights, make its own assessment and make such determination in light of the decisions in Haida ${ }^{18}$ and Taku River Tlingit First Nation v. British Columbia (Project Assessment Director). ${ }^{19}$

\section{OVERLAPPING Claims by INNU PEOPI.ES FROM QUEBEC}

There are other Innu groups from Quebec, namely Sept-Iles (Uashat), Schefferville (Matimekosh), Natashquan and Mingan, who also claim Aboriginal rights in Labrador. Their claims have not been recognized by the Government of Newfoundland and Labrador but have been accepted for negotiation by the Government of Canada and the Government of Quebec. Depending on the location of the project's infrastructure or components, the Quebec Innu may also need to be consulted. The scope of the consultation also depends on the developer's assessment of their claim and the degree of impact expected from the project.

The Mushua Innu of Labrador have established a reserve and any development on reserve lands must comply with the provisions of the Indian ACl. R.S.C. 1985, c. 1.5. A second reserve is also in the process of being completed. IBAs are not a requirement of the Indian Acr. 


\section{B. STATUTORY REQUIREMENTS}

In addition to the common law obligations discussed above, the requirement for consultation may also be legislated.

\section{LAND Cl.AIM AGREEMINTSS}

Once a land claim or settlement agreement has been duly executed and ratified by all parties, the resulting agreement is brought into force under federal legislation and becomes protected under s. 35 of the Constitution Act, 1982. The requirement for consultation and negotiation of benefits with the beneficiaries of the land claim agreement will be set out therein. Such is the case in the Northwest Territories (NWT) ${ }^{20}$

In the NWT, land claim agreements have been legislated in three regions: the Inuvialuit Settlement Region, the Sahtu Settlement Region and the Gwich'in Settlement Region. ${ }^{21}$ The land claim agreements give the beneficiaries ownership of certain surface and subsurface lands within their areas. They also provide for compensation to be paid for access to the lands and provide for certain consultation and benefit rights."?

Pursuant to the Inuvialuit Final Agreement, ${ }^{23}$ an access agreement is required to obtain permanent access across Inuvialuit lands or to exercise rights on Inuvialuit lands to carry out significant commercial activity. Except as otherwise agreed to by the Inuvialuit Land Administration (ILA), a Participation Agreement ${ }^{24}$ is required to set out the appropriate land rent and "rights and obligations of the parties respecting the activity for which the access is being granted."2s. The terms and conditions that may be negotiated with the developer when access is sought include:

(i) costs associated with any inspection of the development work sites and the nature and scope of such inspection:

(ii) wildlife compensation, restoration and mitigation:

(iii) employment, scrvice and supply contracts;

2" For a complete explanation of the legal regime in the NWT, sec Sandy Carpenter, Cecilia A. Low \& John Olynyk. "Oil and Gas Development in Western Canada in the New Millennium: the Changing Legal Framework in the Northwest Territories, the Yukon, and Oftshore British Columbia" (2001) 39 Alta. L. Rev. 1.

2) An AlP has been reached with the Dogrib First Nation in the northeast part of the NWT. Land claim negotiations continue in the southern Deh Cho area.

:In the unsettled land claim areas, the sources of the requirement to consult and negotiate IBAs are the common law duty to consult, the requirement for a benefits plan under the Canada Perrolenm Resources Act, R.S.C. 1985 (2d Supp.), c. 36 [CPRA] or Canada Oil and Gas Operations Act, R.S.C. $1985, \mathrm{C}, 0.7[C O G O A]$ and the general regulatory requirement to consult and to mitigate impacts from the proposed project.

$\because$ Department of Indian and Northern Afrairs Canada. The Hestern Arcerc Claim: The Inuvialuif Final Agreement (Otawa: Indian and Northern Affairs Canada, 1984) (IFA]

$\therefore$ Several Participation Agreements are currently in place with the Inuvialuit Regional Corporation (IRC) ill respect to exploration activily on Inuvialuit Lands. The IRC provides a well-established template agreement for a resource developer to review. New developers are generally expected to meet or exceed the benefits received from exploration projects to date.

: IFA, supra nole 23. s. 10 
(iv) education and training; and

(v) equity participation or other similar types of participatory benefits. ${ }^{26}$

With respect to Crown lands and " $7(1)(b)$ lands," "general guidelines developed by governments relating to social and economic interests, including employment, education, training and business opportunities to favour natives, shall be considered and applied, as reasonably as possible, to each application for exploration. development or production rights." ${ }^{28}$ These objectives may be voluntarily addressed in the form of a Cooperation Agreement between the ILA and the holder of rights.

In the Sahtu and Gwich'in settlement regions, the Sahtu and Gwich'in have the right to manage and control the use of their lands. ${ }^{29}$ This right includes the development and administration of land management programs and policies and the charging of rents or other fees for the use and occupation of their lands.

Both agreements contain very similar requirements to consult before any oil and gas exploration takes place and again before development or production. The matters to be consulted on include:

(i) environmental impact of the activity and mitigative measures;

(ii) impact on wildlife harvesting and mitgative measures;

(iii) location of camps and facilities and other related site-specific planning concerns;

(iv) maintenance of public order, including liquor and drug control;

(v) employment of participants, business opportunities and contracts, training orientation and counselling for employees who are participants, working conditions and terms of employment;

(vi) expansion or termination of activities;

(vii) a process for future consultation; and

(viii) any other matter of importance to the Gwich'in and Sahtu or the person proposing the activity.

The Sahtu agreement also requires that a person who proposes to explore for, develop or produce oil and gas submit a benefit plan to the Minister of Indian Affairs and Northern Development for approval. ${ }^{30}$ The Minister may require that the benefits plan contain provisions to ensure access to training and employment opportunities and to facilitate participation in the supply of good and services. The proponent is then required to consult with the Sahtu Tribal Council prior to submission and implementation of the plan.

bid., s. 10(3).

The Intuvialuit own the surface but not the minerals of $7(1)(b)$ lands.

IFA, supra note 23, s. 16. Cooperation Agreements are currently being negotiated by Imperial Oil, Shell Canada and Conoco-Phillips for their respective field developments for the proposed Mackenzic Valley Pipeline Project. The Mackenzic Valley Pipeline Project consists of three anchor field developments. a gas gathering system and a mainline transmission pipeline.

Department of Indian and Nortluern Afrairs Cauada. Gwich in Comprehensive Land Claim Agreemen' (Ottawa: Indian and Northern Affairs Canada, 1992); and Department of Indian and Northern Aflairs Canada, Sahtu Comprehensive Land Claim Agreemen (Otawa: Indian and Northern Afrairs Canada. 1993).

Sahm Comprehensive Land Clain Agreement, ibid., s. 22.2.I(a). 
Finally, in both the Gwich'in and Sahtu settlement regions, access authorizations are required to access settlement lands. These access authorizations include terms and conditions for access, including compensation, and may also be viewed as IBAs.

\section{OIL AND GAS LEgISLATION}

Statutes governing oil and gas activity on Crown lands in the NWT contain general requirements for the negotiation of benefits.

Section 5(2) of Canadian Oil and Gas Operations $A \mathrm{Ar}^{31}$ requires approval of a benefits plan before any work or activity is authorized. "Benefits plan" under this piece of legislation is defined to mean a plan "for the employment of Canadians and for providing Canadian manufacturers, consultants, contractors and service companies with a full and fair opportunity to participate on a competitive basis in the supply of goods and services used in any proposed work or activity referred to in the benefits plan." 12 As part of this plan, the National Energy Board (NEB) may require that disadvantaged individuals or groups have access to training and employment opportunities and to participate in the supply of goods and services in the work program for which the plan was submitted. ${ }^{33}$

The Canadian Petroleum Resources $\mathrm{Act}^{34}$ does not contain a specific provision requiring benefits to local communities but rather references the requirement found in $C O G O A .^{35}$ Section 21 of the CPRA states:

No work or activity on any frontier lands that are subject to an interest shall be commenced until the Minister has approved, or waived the requirement of approval of, a benefits plan in respect of the work or activity pursuant to subsection 5.2(2) of the Canada Oil and Gas Operations Act.

The benefits plan submitted pursuant to this section must generally satisfy the Department of Indian Affairs and Northern Development's (DIAND) Northern Benefits Requirements Associated with New Exploration Projects, ${ }^{36}$ which includes:

(i) expectations on a project proponent to support and encourage the development of regional businesses;

(ii) to optimize the short- and long-term benefits accruing to the north by providing opportunities for involving northem businesses on a full, fair and competitive basis;

(iii) to identify potential business development opportunities;

(iv) to ensure the same expectations are met by all subcontractors;

"COGOA, supra note 22.

lbid., s. 5.2(1).

lbid., s. $5(3)$.

CPRA, supra note 22.

COGOA supra note 22, s. 5.2(2).

The Call for Bids document issued by the Northem Oil and Gas Directorate of DIAND puts the bidder on notice that it will have to comply with the "Northern Benefits Requirements Associated with New Exploration Programs," online: Department Indian and Northern Affairs Canada <www.ainc-inac.ge. ca/oil/act/cal/stan/2002/ben_e.hıml> 
(v) to give first consideration to qualified individuals resident in the regional communities;

(vi) to identify potential employment and training opportunities; and

(vii) to provide appropriate information to concerned individuals, groups and communities.

The requirement for a benefits plan may be waived, and is generally waived, by DIAND for operations of a transitory nature or of short duration. ${ }^{37}$

The challenge for a resource developer is often in structuring its benefits plan to meet its obligations to land claim beneficiaries while ensuring benefits also flow to "Northerners" under the CPRA and "Canadians" under COGOA.

\section{ENVIRONMENTAL LEGISLATION}

Federal and provincial environmental protection legislation also requires a developer to submit an environmental impact statement, which assesses the potential environmental, social, economic and cultural impact of a project.

"Environmental effect" is defined in s. 2(1) of the Canadian Environmental Assessment $A c t,{ }^{38}$ and includes "any change that the project may cause in the environment, including ... the current use of lands and resources for traditional purposes by aboriginal persons." This necessitates a level of consultation with Aboriginal communities, and in fact, one of the stated purposes of $C E A A$ is "to promote communication and cooperation between responsible authorities and Aboriginal peoples with respect to environmental assessment."

A proponent is expected to mitigate impacts from the project and may be required by the Environment Assessment Panel or regulatory authority to negotiate an IBA with affected Aboriginal communities. While the commitments made to any Aboriginal community to mitigate the impacts from a project may be documented in an IBA, IBAs often include mitigation or remedial measures over and above those commitments made during the environmental assessment process. Moreover, the environmental assessment process deals with mitigation of planned or known environmental effects. Aboriginal groups will often want to negotiate through an IBA additional compensation for unplanned events or effects that are more significant than planned. Negotiation of such provisions should be approached with caution so as to avoid a "bottomless pit" of compensation.

Explorers should note that for operations involving access over Sahtu or Gwich'in surface lands, a benefits plan will be required for all significant operations. See Northem Oil and Gas Directorate. Department of Indian and Northern Affairs Canada, Northern Oil and Gas Bulletin 3:3 (September 1996).

19 Ibid., s. 4(1)(b.3). 


\section{Regulatory REQUiREMENTS}

While there are no express regulatory requirements to implement IBAs with Aboriginal communities, regulatory bodies generally require developers to consult with all stakeholders and mitigate the impacts from a project, which can lead to the negotiation of an IBA.

\section{NATIONAL ENERGy BoARd}

The NEB, among other matters, has jurisdiction over interprovincial and international pipelines and development on frontier lands. Pursuant to Chapter 3 of the NEB Filing Manual ${ }^{40}$ the NEB expects the proponent to file a copy of its Aboriginal consultation protocol, if established, along with any documented policies and principles for collection of traditional knowledge or traditional use information, if applicable. The NEB also expects the proponent, if aware of any involvement of the Crown in consultations with the Aboriginal groups with respect to the project, to describe the Crown involvement. While an actual IBA may not be filed in an NEB hearing due to confidentiality reasons, the existence of an IBA may be presented by the proponent as evidence that satisfactory consultation has taken place.

\section{AlBERTA ENERGY AND UTILITIES BOARD}

The Alberta Energy and Utilities Board (AEUB) regulates all energy projects situated wholly within the Province of Alberta. In the AEUB's Guide $56{ }^{41}$ the AEUB sets out a comprehensive public notification and consultation process that must be met prior to filing an energy development application. It is expected that the public consultation requirements be met for all those whose rights may be directly and adversely affected by a project, including "First Nations and Métis."

The AEUB must also consider the environmental and socio-economic impacts of a project. ${ }^{42}$ In drawing its conclusions, the AEUB considers the environmental and socioeconomic assessments, including traditional ecological knowledge ${ }^{43}$ and takes into consideration any commitments made by the proponent to mitigate those effects. These commitments may take the form of an IBA.

National Energy Board, Filing Manual, online: National Energy Board <www.neb-one.gc.ca/ ActsRegulations/NEBACT/FilingManual/Adobe/FMFilingManual_e.pdf $>$

AEUB, Guide 56: Energy Development Applications and Schedules, Oclober 2003 (AEUB) [Guide 56].

12

11

Energy Resources Conservation Act, R.S.A. 2000, c. E-10, s. 2.1.

The recognition of the value of traditional exological knowledge (TEK) has become a standard part of the regulatory process. "Besides public consultation, the recognition of the value of traditional ecological knowledge (TEK) and it's importance in adequately predicting impacts has led to greater participation by traditional users of an area into the EIA [environmental impact assessment] process in some regions. The integration of TEK has become a de facto part of the regulatory regime in Canada's north even in the absence of statutory requirements," to determine whether the project will likely result in a significant adverse effects." Susan A. Joyce \& Magnus MacFarlane, "Social Impact Assessment in the Mining Industry: Current Situation and Future Directions" (December 2001) at I5. online: Natural Resources and Sustainable Developmen < www.natural-resources.org/minerals/CD/docs/mmsd/ topics/social_impact_assessment.pdis. 


\section{Commercial and Corporate Policy Interests}

It is fair to say that legal requirements are not the only reason industry comes to the table to negotiate IBAs. Often the remote location of an energy project will make it in the proponent's best interest to train and hire the local Aboriginal community or to have local businesses supply goods or services. Establishing agreements to ensure these needs are met provides certainty and can reduce costs. Many large corporations have developed "good neighbour" or sustainable development policies that require meaningful engagement with local stakeholders. Finally, it may just make good business sense to enter into an IBA with the local Aboriginal community.

\section{Project Planning Considerations}

In order to ensure projects proposed on traditional Aboriginal lands proceed on budget and on time, the developer should acquaint itself with Aboriginal interests and expectations very early in the planning phase.

\section{A. Timing}

It is critical to do an assessment of Aboriginal rights in the project area early in the project planning phase. There are several reasons for this. Firstly, in order to be meaningful consultation, it must be in good faith with the intention of substantially addressing the concerns of Aboriginal peoples when lands are at issue. ${ }^{\text {t4 }}$ If this principle is to have relevance and meaning, it requires the developer to share project information before final design and irreversible decisions are made. Consultation, as defined in many land claims or settlement agreements, requires that Aboriginal peoples be given sufficient time to review the information presented in order to determine whether there will be any impacts on their Aboriginal rights. ${ }^{45}$ Case law on procedural faimess offers guidance in determining whether sufficient time has been afforded to Aboriginal groups. In $R$. v. Secretary of State for Social Services, ${ }^{46}$ the Court held that the Secretary had failed to fulfill the duty to consult and stated that "sufficient time must be given by the consulting [party] to the consulted party to enable it to do that, [to tender helpful advice] and sufficient time must be available for such advice to be considered by the consulting party. Sufficient, in this context, does not mean ample, but least long enough to enable the relevant purpose to be fulfilled." ${ }^{47}$ For instance, if, as a result of reviewing the project design, it is demonstrated that a particular part of the project impacts traditional hunting grounds, consultation would dictate trying to relocate that part of the project to a place that has little or no impact.

Second, Aboriginal peoples will need time to understand the details of the project before they can truly assess the impacts it will have. This will often necessitate holding community briefings to discuss the nature of the development and the impacts predicted. Consequently,

" Delgamuuku'. supra note 7 at para. 168.

ts See Nisga a Final Agreement Act, S.C. 2000, c. 7; Department of Indian and Northern Affairs Canada, Nisga a Final Agreement (4 May 1999), online: Indian and Northern Affairs Canada <www.aincinac.gc.ca/pr/agr/nsga/nisdex 12_c.pd/> [Nisga'a].

[1986] I All E.R. I64 (Q.B.).

4 lbid. at 167. 
Aboriginal negotiators will need to seek advice from consultants with appropriate expertise to assist them in making an informed decision.

This process typically precedes the direct negotiations of IBAs and may take several months depending on the complexity of the project and the level of sophistication of the parties. In practical terms, the process should start during the pre-feasibility phase, prior to any decision to proceed with the proposed development. Any decision to proceed with a project $^{48}$ without consultation will, in all likelihood, end in confrontation and negative publicity.

Third, engaging in this dialogue and consultation process early in the planning phase will enhance the likelihood of Aboriginal support for the project. Aboriginal peoples might have different views and perspectives on environmental impacts and insist on a process of environmental assessment that is different from legislative environmental assessment regimes. Modifying work scopes and studies to accommodate Aboriginal concerns will alleviate many unanswered questions and avoid duplication of scientific studies.

\section{B. COST IMPLICATIONS}

As previously noted, consultation contemplates participation and compensation, the degree of which can vary depending on the nature of the Aboriginal right and the degree of impact. ${ }^{49}$ Compensation and participation can take many forms. Typically, it will include such benefits as preferential contracting, employment and training opportunities, set-aside contracts, funding for environmental and remedial works and funding for community programs to promote culture and traditional way of life. Many recent IBAs have included provisions for profit-sharing and equity participation. These benefits all have cost implications for the project and should be factored into the financial package being negotiated and the project's overall capital costs. The question usually asked is how much should be budgeted for "Aboriginal consultation"? As suspected, the answer varies.

Financial benefits must be reasonable from the point of view of project economics and should be related to the nature, scale and costs of the development. This is expressly stated in Part 6 of the Labrador Inuit AIP as the guiding principles for IBA negotiations:

6.7.4 Negotiation of Inuit Impacts and Benefits Agreements shall be guided by the following principles

(a) benefits shall be consistent with and promote Inuit cultural goals;

(b) the nature and extent of benefits shall be related to the nature, scale and cosi of the Major Development;

(c) benefits shall not place an excessive burden on the Developer or undermine the viability of the Major Development;

4* Developers should be cautious when publicly announcing a decision to proceed with any development if consultation has not occurred.

4y Delgamuuhy, supra note 7 . 
(d) negative impacts on the Environment, Inuit and Inuit rights under this Agreement shall be avoided, [m] jitigated or compensated in a manner consistent with the nature. scale and cost of the Major Development: and

(e) Inuit Impacts and Benefits Agreements shall give priorities to Inuil but shall not preclude other residents adjacent to the Zone from obtaining benefits from the Major Development. ${ }^{\text {so }}$

However, the financial terms and conditions of an IBA must also meet a number of interrelated criteria such as reasonable present value, long-term benefits and other incentives to facilitate the project.

Previous IBA provisions can offer some insight as to what has been negotiated in the past. However, financial precedents must be approached with caution as each project has unique factors that should be distinguished. One should consider the nature, size and scale of the project that is the subject of the IBA, the Aboriginal rights at stake, the extent of environmental impacts associated with the project, whether any land claims settlement provided royalties in conjunction with the project and whether part of the compensation provided was for past environmental damage. For example, a financial package of $\$ 80$ million may be reasonable for a hydro development of $1200 \mathrm{MW}$ but not for a small project of $150 \mathrm{MW}$. A larger project may also impact more than one Aboriginal group and therefore the payment may be larger to accommodate this. Moreover, larger projects tend to have greater impacts and consequently, require greater compensation.

Given the confidentiality of IBAs and in particular the financial components, it is difficult to summarize with accuracy the size of the financial package. A review of several mining and hydro-electric IBAs revealed that financial payments represent a very low percentage of the project's overall capital costs and can vary from 15 to 50 years.

In attempting to value the cost of Aboriginal participation, developers should keep in mind that contractors will typically add to the cost of any bid for project work, requirements to provide Aboriginal employment, on the job training or other special considerations for Aboriginal peoples.

\section{NEGOTIATING IMPACT BENEFIT AGREEMENTS}

\section{A. Proper Parties}

It is critical in fulfilling the duty to consult to ensure that the proper Aboriginal groups are consulted. Aboriginal groups whose occupation and use of the land naturally establish Aboriginal or treaty rights need to be consulted and, in the absence of a court declaration or land claims or settlement agreement, it is up to the developer to study the factual aspects that underpin a claim or an allegation of a claim to such rights. Justice Lambert in Haida (C.A.) ${ }^{\text {s1 }}$ 
confirmed the obligation to consult in the absence of a conclusive determination of Aboriginal rights. In its reasoning, the Court stated:

How could the consultation aspect of the justification test with respect to a prima facie infringement be met if the consultation did not take place until after the infringement? By then it is too late for consultation about that particular infringement. ${ }^{52}$

In this context, the duty to consult and accommodate arises from the broader fiduciary relationship between the Crown and Aboriginal peoples. ${ }^{53}$

Moreover, where overlapping traditional claims are supported by credible evidence, all the affected Aboriginal groups in question must be consulted. ${ }^{34}$

In cases involving more than one Aboriginal group it is not uncommon to reach agreement with one group and not another. To minimize the risk of legal challenge by disgruntled groups, the Supreme Court in British Columbia recommends negotiations with umbrella organizations:

This Court should be slow to accept the submissions of one band when it is not joined in by its umbrella organization authorized to negotiate Ireaties on their behalf. ${ }^{55}$

Guidance can also be found in the federal government policy on management of comprehensive land claims:

In determining the group that is eligible to negotiate a comprehensive claims agreement, the federal government should respect the aboriginal peoples' traditional groupings and organizational structures. Aggregation should be encouraged to the highest level acceplable to the aboriginal communities involved. The government should avoid taking positions that would foster the fragmentation of aboriginal organizations, which would exacerbate overlap problems and add considerably to the complexity and costs of negotiations. Aggregation of claims should not be pushed to the point at which aboriginal peoples with quite different perspectives and aspirations are forced to negotiate together. ${ }^{56}$

In Labrador, the Nunavik Inuit as represented by the Makivik Corporation challenged a decision of the federal government to reserve lands for a national park in Labrador. Notwithstanding the fact that the Province of Newfoundland and Labrador does not recognize their claim to lands in Labrador, the Federal Court of Canada ruled that the Government of Canada had a duty to consult and negotiate in good faith with the Nunavik Inuit in relation to the proposed national park. ${ }^{57}$ 
In Kelly Lake, ${ }^{58}$ the Kelly Lake Cree Nation alleged that it had not been consulted in relation to the development of an exploratory gas well. The Crown had consuited those bands that had either established rights or asserted rights in close proximity to the development. However, given the remoteness of the Kelly Lake Cree Nation to the area in question and the fact that the Kelly Lake Cree Nation had not asserted land claims with respect to the area prior to 1995, the Court did not find the Crown had a duty to consult them.

There are many umbrella organizations and incorporated entities negotiating on behalf of Aboriginal groups. As many are not creatures of the Indian $A C l,{ }^{59}$ it is necessary to verify their rules of mandate to ensure they have the proper authority to negotiate at the table. Likewise, it is prudent to validate the negotiator's mandate with the organization's leaders and, if necessary, the band council.

The negotiators mandate should be verified early in the negotiation process to ensure that positions negotiated and information shared are binding on those they represent. Depending on the political structure and governance of the body negotiating on behalf of the Aboriginal group or a requirement in a land claims agreement, it may be necessary to ratify the IBA to ensure the community is fully informed of the provisions and, possibly, concessions contained in the IBA.

As a matter of practice, provisions outlining the negotiator's mandate and authority to represent the members of the band or Aboriginal group should be reflected in a framework agreement or negotiated early in the IBA negotiations to avoid any misunderstandings and unnecessary delays.

\section{B. GoOD FAJTII}

Regardless of the scope, consultation must be in good faith with the intention of substantially addressing the concerns of Aboriginal peoples. Good faith in the context of consultation is a standard to govern the exchange of information and accommodation of sometimes differing views. Given the lack of clarity with which case law has defined consultation, negotiators and governments have seen it appropriate to define the term in their agreements. In the Nisga'a Final Agreement, ${ }^{60}$ the parties defined "to consult" as follows:

(a) notice of a matter to be decided, in sufficient detail to permit the party to prepare its views on the matter,

(b) in consultations between the Parties to this Agreement. if requested by a Party, sufficient information in respect of the matter to permit the Party to prepare its views on the matter,

(c) a reasonable period of time to permit the Party to prepare its views on the matter,

(d) an opportunity for the Party to present its views on the matter, and

(c) a full and fair consideration of any views on the matter so presented by the party. 
This negotiated definition summarizes many aspects of what it means to consult in good faith. Jurisprudence in Canada and Australia has elaborated more fully on several aspects of this definition such as the level of information disclosure, ${ }^{61}$ the duty of the Crown and developers to be informed of the practices and views of the Aboriginal groups affected, ${ }^{62}$ and the time frames granted by the developer to assimilate the information. ${ }^{63}$

The following indicia were identified by an Australian tribunal in the $\mathrm{Njamal}^{\text {to }}$ case of 7 August 1996 and accepted by the Federal Court of Australia in the case of Walleyv. National Native Title Tribunal, ${ }^{\text {os }} 6$ January 1999 in determining whether the government had negotiated in good faith:

(i) unreasonable delay in initiating communications in the first instance;

(ii) failure to make proposals in the first place;

(iii) the unexplained failure to communicate with the other parties within a reasonable time:

(iv) failure to contact one or more of the other parties:

(v) failure to follow up lack of response from the other parties;

(vi) failure to attempt to organise a meeting between the native title holder and granlec parties:

(vii) failure to take reasonable steps to facilitate and engage in discussions between the parties;

(viii) failing to respond to reasonable requests for relevant information within a reasonable time;

(ix) stalling negotiations by unexplained delays in responding to correspondence or telephone calls;

(x) unnecessary postponement of meetings;

(xi) sending negotiators without authority to do more than argue or listen;

(xii) refusing to agree on trivial matters, for example, a refusal to incorporate statutory provisions into an agreement:

(xiii) shifling position just as agreement seems in sight:

(xiv) adopting a rigid non-negoliahle position;

(xv) failure to make counter proposals;

(xvi) unilateral conduct which harms the negotiating process, for example, issuing inappropriate press releases;

(xvii) refusal to sign a written agreement in respect of the negotiation process or otherwise;

(xviii) failure to do what a reasonable person would do in the circumstances.

The duty to consult in good faith also requires Aboriginal groups in consideration thereof to participate in good faith in the consultation process. Aboriginal people have an obligation not to frustrate attempts by the Crown or to consult with them by refusing to participate or by placing unreasonable conditions on government.

There is a reciprocal duty on aboriginal peoples to express their interests and concerns once they have had an opportunity to consider the information provided by the Crown, and to consult in good faith by whatever

"1 Cheslana Carrier Nation v. British Colmmbia (Environmental Assessment Act, Project Assessment Director) (1998), 53 B.C.L.R. (3d) I (S.C.).

(1) Halfivay River First Nation v. Brifish Columbia (Minister of Forests) (1999), 178 D.L.R. (4th) 666 (B.C.C.A.) [Halfiray River].

R. v. Noel, [1996] N.W.T.R. 68 (Terr. Ct.).

it Western Australia v. Taylor (1996). 134 F.L.R. 211 at 224-25 (National Native Title Trib.) [Njamal].

is 1999 FCA 3 
means are available to them. They cannot frustrate the consultation process by refusing to meel or participate, or by imposing unreasonable conditions. ${ }^{66}$

In fact, a refusal to participate in discussion may prevent an Aboriginal group from complaining about a lack of consultation. ${ }^{67}$

\section{Key Provisions in IBAS}

It is trite to say that IBAs are more than a mere response to legal and policy requirements. They are a response to a complex set of economic and social issues that arise when a development is proposed on Aboriginal lands. Consequently, the provisions of each IBA will vary depending on the impacts that result from the project and the manner in which affected Aboriginal groups would like to have them addressed. Much has been written on the contextual elements of $1 \mathrm{BAs}{ }^{63}$ and will not be repeated here. Rather, this part of the article will focus on those provisions that have a greater impact on project economics and operations and that are becoming more contentious.

\section{A. BUSINESS AND EMPLoYment OPPORTUNities}

Business and employment opportunities for Aboriginal peoples and businesses are a common form of participation and, indirectly, compensation. However, the socio-economic reality and lack of capacity of many Aboriginal communities may preclude them from availing themselves of many of these opportunities. Depending on the type of project, many of the higher paying jobs require a minimum level of education and experience in a specialized field of technology. Moreover, the local Aboriginal labour force may be tapped out by commitments to other projects in the area. Many Aboriginal businesses also lack experience and financial stability and therefore are not in a position to compete for the work. If developers and Aboriginal people want to maximize benefits from these opportunities, both sides need to discuss labour force requirements and capacity early in the consultation process. The following benefits are becoming more common in IBAs and reflect a level of Aboriginal expectation across Canada.

\section{EMPLOYMENT AND TRAINING}

One of the most important objectives of IBAs is to provide employment opportunities to local Aboriginal workers. This is due in large part to the high rates of unemployment found in remote areas where many of the oil and gas activities are taking place. The challenges often include preparing workers for the jobs available, facilitating entry into the workplace, implementing appropriate measures to address cross-cultural issues and retaining Aboriginal employees over the long-term.

et See Steven A. Kennett, A Guide to Impact and Benefits Agreements (Calgary: Canadian Institute of Resources Law, 1999). 
Typical IBA provisions include:

- A preferential recruitment and hiring policy for local Aboriginal workers;

- A process to identify actual and potential employment opportunities and the skills and qualifications required to perform the specific jobs;

- An annual employment plan to enable the Aboriginal community to plan for the opportunities;

- A commitment to consult with the Aboriginal community regarding job opportunities and the potential workers that may be able to fulfill them;

- An agreement to set reasonable qualifications for specific job categories;

- Commitments to training and apprenticeship programs, educational programs in primary and secondary schools, donations to scholarships and bursaries, participation in local career days, stay-in-school programs, etc.;

- An employment support system to assist individuals and the community in adapting to the project workplace that may include cross-cultural training for both Aboriginal and non-Aboriginal workers;

- Workplace policies that may include flexible work schedules to accommodate traditional activities such as hunting, trapping and ceremonies;

- Termination procedures that require the company to provide a full explanation for the dismissal;

- A requirement that all employment obligations shall be applied to contractors and subcontractors; and

- Periodic review of the level of Aboriginal employment at the project and the effectiveness of employment practices.

For longer-term projects, such as an oil sands mine or the operation of a gas plant, an investment in the local labour force may make good business sense as a steady supply of local labour is needed and the cost of bringing in workers to a remote area can be high. For shorter-term projects, such as a seismic program or pipeline construction, typical employment provisions may need to be adjusted to reflect the intense, short-term nature of the work. Where a developer has difficulty identifying long-term jobs within its organization, it may be able to accomplish its employment commitments by requiring its local contractors to hire locally.

\section{BUSINESS OPPORTUNITIES AND PREFERENTIAL CONTRACtING}

From an Aboriginal perspective one of the most significant benefits from project development are the business opportunities that can be derived. Most IBAs include provisions to provide Aboriginal people and Aboriginal businesses with opportunities to supply many goods and services to the project on a contract basis, including first opportunity and set-aside contracts for such services as translation and cross-cultural training.

Typical provisions include:

A commitment to take reasonable or best efforts to provide the Aboriginal community with the opportunities to supply goods and services where the local 
businesses have the capacity to supply goods and services in a safe, competitive and timely manner;

- A requirement to extend the agreements made to contractors, subcontractors and suppliers;

- A specified tender procedure that may require bids to be solicited first from the Aboriginal community;

- Competitive bid criteria that include "Aboriginal content";

- Preferential contracting where no tender is required; and

- First opportunity to negotiate certain contracts.

Of concern to Aboriginal people during the negotiations of these benefits is the weight to be afforded "Aboriginal content" in the bidding process, ensuring local Aboriginal businesses are not screened out at pre-qualification stages and ensuring that larger contracts are broken down into small enough contracts such that local businesses can compete.

From the industry perspective, developers will want to minimize cost and ensure the best possible quality and service. The following pre-established criteria are typically acceptable to both sides:

- Quality, including technical and operational capability;

- Cost competitiveness;

- Ability to supply and deliver the goods and services to be provided;

- Timely delivery;

- Safety and environmental record;

- Aboriginal content; and

- Other generally accepted industry criteria such as follow-up service.

The definition of "Aboriginal business" and "Aboriginal content" varies in each IBA. This is often a sensitive issue for both sides given the tendency of indjviduals to form Aboriginal companies to take advantage of preferential contracting opportunities. DIAND has defined an Aboriginal business as having greater than 51 percent Aboriginal ownership and control and, if more than six emplnyees, 33 percent Aboriginal employees. What can and often results is an Aboriginal business being formed to meet the definition of Aboriginal content criteria that does not provide any real benefits to Aboriginal peoples. Further, forming joint ventures with Aboriginal businesses to meet the definition may also result in unfair consideration, meaning the Aboriginal business may bring value to the table (assets, knowledge, skills, human resources, etc.). In order to achieve the benefits objectives, developers may need to look beyond Aboriginal ownership of the company and determine whether there is significant Aboriginal benefit, ownership, control and/or employment. However, the less objective the standard in defining an Aboriginal business, the greater the potential for abuse by Aboriginal and non-Aboriginal businesses wishing to take advantage of preferential contracting.

Cost competitiveness is also an important issue for developers as the cost of supplying goods and services can have a major impact on the economic viability of a project. As a general rule, the project proponent will be seeking to keep control over its decision to evaluate the cost competitiveness of a bid. The Aboriginal community may accept that the 
determination be made by the company involved but may be seeking transparency in the process, and possibly a third-party auditor to ensure the bid criteria are being followed.

\section{FIRST OPPORTUNITY}

An operational model of first opportunity can be found in the Inuvialuit region. The Imuvialuit Final Agreemen ${ }^{69}$ specifically provides that a Participation Agreement addressing matters such as employment, business opportunities and education is required for access to Inuvialuit lands. These benefits are to flow to the beneficiaries of the IFA in the first instance, which effectively provides the beneficiaries with "first opportunity" status. The Inuvialuit Regional Corporation has taken this a step further by establishing an "A" list of Inuvialuit businesses and an Inuvialuit Business List, commonly known as the " $B$ " list. Several of the Participation and Comprehensive Cooperation Benefits Agreements negotiated to date include a requirement for the developer to first source its goods and supplies from the " $A$ " list. ${ }^{70}$ If the goods or services cannot be provided by the " $A$ " list of companies, then the developer can tender the work but only to the " $B$ " list of companies. Only if no competitive bid is received from the " $\mathrm{B}$ " list of companies can the developer tender the work outside the Inuvialuit region.

In contrast, Shell Canada Limited (Shell) and other companies in the oil sands area have purposely stayed away from first opportunity. In the region, there are at least five Aboriginal communities in the immediate area and the community of Fort McMurray is close by. Shell has taken a principled approached and implemented a "Good Neighbour Policy" for the purpose of developing mutually prosperous, long-term partnerships with people living in its operating areas, "particularly First Nations and Métis people living close to the Muskeg River Mine." The Good Neighbour Policy includes using and encouraging local business services - including First Nations and Métis businesses "where they are competitive and can meet requirements" and ensures that jobs created will be filled by its neighbours "whenever possible - but always on a strictly merit basis." ${ }^{.71}$

Other IBAs have attempted to set aside a percentage of contracts to be made available to Aboriginal businesses and set employment targets. For reasons previously cited, this approach can only lead to higher expectations from Aboriginal groups and a sense of failure for both sides if the targets are not met. Developers should be cautious that failure to meet employment or contract targets do not trigger a breach of the IBA. It is recommended that such targets be a desirable objective to attain but not be binding on the developer.

\section{B. Capacity Bullding}

It is an unfortunate reality that many of the Aboriginal communities do not have the capacity to take advantage of the employment and business opportunities that do come their way. In the past, industry has often exacerbated the problem by imposing rigid requirements

II The Inuvialuit business must be able to supply the goods or services on a competitive basis and in accordance with the company's health and safety standards.

" Shell Canada Limited, "Engage and Work with Stakeholders," online: Shell Canada Limited <www. shell.ca/code/products/oilsands/sustainable/hssd_stakeholders.html>. 
that preclude many Aboriginal individuals. For example, a requirement for a Grade 12 education can effectively exclude the majority of local workers. ${ }^{22} \mathrm{~A}$ requirement that a company demonstrate a clean safety record or provide financial security bonds can effectively preclude many Aboriginal start-up companies, newly formed to try to take advantage of the business opportunities that are to accompany the proposed project. Today, these issues are generally being recognized and efforts are being taken by industry to help bridge the gap.

Effective IBAs address the need to build the capacity of the community. Capacity building can be accomplished in many ways including:

Conducting workshops with local businesses to explain the tendering process and development of business skills to submit a competitive bid;

Working with schools and government to promote education and encourage students to complete secondary school;

- Funding scholarships to enable students from affected communities to undertake post-secondary studies; and

- Joint venturing with Aboriginal businesses.

In Alberta, capacity building is being recognized as part of long-term relationship building. Memorandums of Understanding (MOUs) to document the commitments made are becoming more commonplace, particularly in the vicinity of traditional oil and gas operations. ${ }^{\text {n }}$ The terms of these non-binding MOUs may not be related to a new project but rather focus on long-term relationship building and contemplate non-exclusive employment and business opportunities. Regional initiatives to build capacity are also being formed. ${ }^{74}$

\section{Financial Provisions}

Financial provisions in an IBA serve two main purposes: to compensate Aboriginal groups for any impacts that may be associated with a proposed development pursuant to the duty to consult and to garner support for the project by ensuring Aboriginal peoples receive direct economic benefits from the project. Consequently, the overall financial package will vary from one project to another and the method of payment can be as creative and inventive as the parties negotiate.

In drafting financial provisions, it is important to keep in mind that financial issues are not just monetary targets but rather capture the nature of the expected relationship between

To accomplish their employment objectives, developers may need to relax their formal education requirements for workers who may have significant related experience or be prepared to provide on -thejob training.

For example, Shell has entered into one near its Waterton Plant in Southem Alberta and is currently negotiating a second one in northwest Alberta. Husky Energy has at least five (5) MOUs in place with First Nations in northern Alberta.

The Athabasca Tribal Council/Athabasca Resource Development Working Group (ATC/ARD) has been established in the oil sands area. The ATC/ARD focuses on capacity building for the five First Nations of the Wood Buffalo region in the areas of environmen/consultation, jobs and education, human infrastructure and physical infrastructure. Membership includes representation in the Athabasca Tribal Council, three levels of government and resource developers. 
project proponents and Aboriginal peoples. They are but one piece in a very complex exchange of rights and obligations.

The growing trend in IBAs has shifted from one-time cash payments 10 more participatory and business-orientated relationships. Aboriginal people are better positioned today to negotiate longer-term benefits for future generations as well as short-term benefits. Consequently, IBAs are seeing more profit-sharing arrangements and equity participation to secure this commitment.

As previously noted, financial benefits should reflect the nature, scale and cost of the development. Payments should be sufficient for Aboriginal peoples but not so burdensome to the project as to jeopardize project economics. Payments should provide incentives for support, adherence to time lines and efficiency and the structure should enhance the overall commitment to the project.

IBAs generally contain a mix of fixed and variable payments. Fixed payments typically coincide with milestones, such as the execution of the IBA and the date the project receives authorization. It may be a payment to establish community or remedial funds with varying purposes and administrative mechanisms. Other fixed payments can compensate for negotiations and implementation costs.

Profit-sharing and equity participation are obvious incentives to both parties to commence and operate the project in a timely and efficient manner. Some IBAs offer investment profitsharing arrangements where Aboriginal groups can invest in the project and receive dividends tied to the success of the project. The formation of joint participation arrangements or partnerships require careful planning and allocation of responsibilities for management and control. A more detailed discussion of the factors that should be considered follows.

\section{Structuring Commercial. Relationships}

The true nature of an effective and lasting benefits arrangement between a developer and an affected Aboriginal group will be evident in the final form of their social and commercial relationships. While benefits such as training, employment, infrastructure and the supply of goods and services are direct and meaningful, it leaves the developer with the exclusive ability to direct the pace and direction and reap the long-term rewards of a particular project.

Through experience and past learnings, resource development companies recognize the potential synergies of joining together to promote a particular project. Business partnerships with large industrial consortia represent a chance for Aboriginal groups to achieve significant advances in financial independence and obtain an influential voice in developments affecting their lands.

\section{A. Aboriginal perspectivei on Participation}

Experience has shown that Aboriginal groups who seek some variety of project participation on a working interest basis consider the following matters while they establish their investment vehicle and negotiate commercial agreements to formalize that participation. some of which have been touched on earlier: 
A legislated or contractual right to participate (for example, s. 10(3)(e) of the Inuvialuit Final Agreement, as amended);

The legal entity or corporate vehicle to be used for project participation should contribute maximum long-term benefits to the affected Aboriginal people:

Participation in a particular project must lead to greater opportunities for commercial involvement in the local and national economies;

A "seat at the table" must give direct and meaningful input into decisions controlling whether a project proceeds, a project's scope, facility placement, training, education, long-term skilled employment and local contracting;

Direct participation should assist in the maximization of Aboriginal benefits;

Direct involvement as a project owner should enhance the effectiveness and completeness of the community consultation process;

Direct participation and input regarding all requisite studies, planning and operations should ensure maximum protection of the environment, cultural resources and traditional commerce;

A "financial stake" should result in increased independence and self-reliance in the Aboriginal community;

- Direct involvement should provide an opportunity to have a "window on the process" for monitoring the quality and quantity of benefits and compensation being received by Aboriginal individuals, businesses and communities; and

- Participation should foster and promote developers' respect for the land, environment and cultures of Aboriginal peoples.

\section{B. Industry Perspective on PARTicipation}

Industry proponents also have certain expectations and requirements for participation by an Aboriginal group. Broadly stated, they will consider the following matters regarding a potential participating Aboriginal entity while retaining their focus of ensuring a low cost, financially stable and efficient project:

The economic interests an Aboriginal group (or its constituent elements) may have in the region;

Their management or ownership of significant commercial assets by way of corporations or other legal or legislated entities;

Its capability of funding its working interest share of the long-term project financial requirements;

Its forbearance from supporting competing projects;

Whether it is willing to actively support, promote and provide assistance required to obtain all necessary licences, permits and approvals;

Whether it will cooperate and assist the project operator in the community consultation process;

The Aboriginal communities the particular entity represents;

Whether the prospective participant is capable and willing to bind itself to continue to represent its original Aboriginal constituencies;

Whether it will assist in achieving full and fair access and benefits agreements with affected Aboriginal communities;

Whether their participation will facilitate favourable tax arrangements or agreements with respect to, for example, business or property taxes; 
Their ability to contribute their own natural resource reserves (minerals, oil and gas, forestry, quarryable material, etc.);

Their financial capability in the form of equity or debt or any combination thereof, possibly including government grants, loan guarantees or other backstopping; and Their ability to provide insight into aspects of traditional and cultural expectations and requirements, together with how they can be satisfied in the course of the project.

\section{ANalysis of Project Structure}

Project proponents should not consider the number and type of participants in isolation from other factors. Proponents must concurrently reflect upon the final form of the project since it is often influenced by each potential participant's legal organizational structure, as well as that of the unified venture. The decision-making process for selecting an optimal project structure should include maintaining a perspective that presumes not only some sort of Aboriginal direct participation but considers the form of legal entity such participation may take. It is useful to investigate how industry proponents select project structures since each of the many elements that affect the decision represents an opportunity for the initial proponents to judge the impact of Aboriginal participation. Of course, it is also true that a potential Aboriginal group will need to go through the same process in choosing their own structure.

The appropriate project structures will depend to a large extent upon the size of the financial and technical risks. For many years the oil and gas industry had historically chosen to spread its risks through the use of unincorporated joint ventures for such operations as drilling wells, constructing batteries, gathering systems and processing facilities. Since the debut of megaprojects and the fact that industry has been forced into ever more remote areas to search for and develop reserves, the cost, environmental sensitivity and complexity of many projects has spurred companies to consider the potential use of the many options available to them. Among these numerous options, consideration may be given to a joint venture, partnership, single purpose company (with limited or unlimited liability), limited partnership or joint venture with operating company (with the latter having no beneficial interest in assets).

Selecting the structure that best suits a particular project and its participating owners can be a complicated analytical process that involves reviewing the applicability, impact and flexibility afforded by a great number of variables, any one of which may be found to be advantageous, manageable, neutral or a roadblock. All of the following matters (and many more minor ones that will be of importance to individual companies) will have a specific degree of advantage or disadvantage allotted to it as a result of this analysis:

Financing issues such as creditworthiness and effects on tolls;

Transferability of ownership interests, consents and preferential rights;

Legal issues of limited liability and several or joint liability;

Structural governance issues affecting control, costs, efficiencies and complexity;

Project staffing considerations of secondments and operator's experience; and

Tax and accounting issues such as flow through benefits and sales of interests. 


\section{VARIATIONS OF PARTICIPATION STRUCTURES}

Once consideration is given to the general determinative elements in the choice of a project structure, the initial industry proponents and the prospective Aboriginal participant will be required to settle upon not only which legal structure is optimal but which method (from a multitude of variations) of Aboriginal participation is achievable and preferable. Without hoping or attempting to catalogue a complete choice of options, the following are variations for participation and funding of an Aboriginal participant's working interest:

- It would pay 100 percent of its ownership or working interest share of all project costs (the normal situation);

- It would have the other participants pay 100 percent of its share of its voting ownership or working interest share of all project costs (a "full carried interest"); It would be given a nominal non-voting ownership or working interest (or observer status) for an initial period of time and after that time, or when the project has achieved a specific development or operational milestone, then pay its full working interest share of project costs (a "back-in") for a full ownership or working interest;

- It would fully fund an initial ownership or working interest and have pre-established rights to purchase additional ownership or working interests from the other participants at various times in the future or have priority rights of first refusal on dispositions; or

- It would be carried at different decreasing working interest levels while concurrently being required to meet certain increasing funding levels as specific project development or operating milestones are achieved (such that during predevelopment and construction phases it would maintain a 10 percent working interest of which it funds 25 percent and the others fund 75 percent, changing to a respective 50-50 funding split at start-up, a 75-25 percent funding split for the first five years of operations and full funding thereafter).

The number of variations to the above are, as usual, limited only by the inventive legal and financial minds that provide counsel to a project. Additional variations can be generated (i) if debt financing (as opposed to a carried interest) is provided by third parties or by project participants, and (ii) depending upon what scenarios and at what times the Aboriginal group is afforded voting rights.

\section{ENFORCEABILITY}

While much time is spent on negotiating business opportunities and key IBA provisions such as financial compensation, social and cultural protection and employment opportunities, there is little focus given to the enforceability of IBAs. This is partly due to the fact that IBAs are viewed as commercial contracts between the developer and the affected parties and enforceable under contract law. As found in many commercial contracts, IBAs also contain "governing law" provisions, in other words, a legally binding contract subject to general laws of application and shall be interpreted in accordance with the laws of a specified jurisdiction. However, the provision has not been judicially tested in the context of an IBA.

Investors are sensitive to any negative impact on their investment and may want assurance from developers that the project has the support of the local communities. No doubt, 
investors are aware that with the financial support of many non-governmental organizations, Aboriginal groups are well positioned to cause significant delays through injunctive proceedings and negative press if their rights are perceived to be violated.

While profit-sharing and ownership provisions give great comfort, they do not address the question of enforceability. Until an IBA is challenged in court, there are certain precautions that should be noted and, to the extent possible, addressed in the IBA.

First, in order to avoid a challenge on the basis of unequal bargaining positions, the developer should ensure there is a level playing field during the negotiations. This may often entail providing funding to the Aboriginal group(s) for financial, legal and other specialized counsel. This may be reinforced with provisions indicating the contract was executed in good faith, without any undue force or coercion, and was signed voluntarily having had independent counsel and advice regarding the nature and substance of its contents.

Second, the developer should be certain that all the parties affected by the development are consulted and the level of participation/compensation is fair and equitable in the circumstances. Unfortunately, there is no test by which to measure adequate consultation, but there should be a balance between the level of compensation and the impact of the project. Moreover, financial benefits should not be so burdensome as to affect project viability.

Third, the developer must ensure that the negotiators, on behalf of the Aboriginal group(s), have the requisite mandate and authority to negotiate the IBA and that the proper parties have executed the document. A provision to this effect should be included. Any uncertainty as to the ability of the organization to bind the community should be resolved in favour of ratifying the IBA at the community level. It is recommended that provisions that speak to the interpretation of the contract on the basis of equitable and remedial principles should be avoided as this may open the door to an interpretation based on something other than pure contract principles.

Fourth, a provision that confirms that the organization and the Aboriginal groups they represent will not bring any action or proceeding that will have the effect of delaying. hindering or preventing the project from proceeding should be included. It is recognized that this may be problematic as the party negotiating cannot guarantee that third parties will not bring such a claim. However, an agreement to defend or assist the company in its defence of such a claim should suffice and address this concern. If applicable, there should be a covenant to the effect that the Aboriginal group will not advance any land claim that will negatively impact or impede the project.

Fifth, developers should ensure that the Crown is advised of the substance of the negotiations, is satisfied with the level of consultation and, if possible, signs off on the IBA. This is in recognition of their fiduciary duty towards Aboriginal peoples in the event it is later challenged that the Crown did not advance a position that is in the best interests of the Aboriginal groups affected.

Sixth, if any part of the project takes place on reserve lands, obtain the appropriate licences or permits from the appropriate minister as well as band resolutions. 
Despite all of these precautions, there still remains the question of whether the proposed activity, if contrary to the nature and exercise of Aboriginal rights, will be binding and enforceable. More importantly, can the Aboriginal group affected by the project waive enforcement of its Aboriginal right? These issues may be addressed if the proposed development has a valid legislative objective and meets the test set out in Sparrow. ${ }^{75}$

The bottom line is that the validity and enforceability of an IBA is part of emerging law, to be determined at some future date.

\section{CONCLUSION}

Case law in the area of consultation is rapidly emerging and the standards for industry have been heightened. Once seen as the Crown's fiduciary obligation, the duty to consult has now shifted to the developer. If consultation is not conducted properly, in good faith and with the appropriate parties, developers might lose valuable time and money or even have authorizations revoked. Unfortunately, there is no objective tool for which to measure adequate or sufficient consultation. Notwithstanding the lack of objective clarity, one element is constant throughout the body of case law: consultation must be fair both on a procedural and a substantive basis. Procedurally, Aboriginal people must be given the opportunity to present their views and have them seriously considered and accommodated. Case law on procedural fairness and equity assist in determining whether this element has been achieved. Substantially, case law states that Aboriginal rights must be accommodated. Accommodation can vary from case to case and includes an attempt to develop the project in a manner that minimally impairs Aboriginal rights and where there are impacts, to mitigate those impacts. Where mitigation is not possible, compensation may be appropriate.

Consultation is not required to produce an IBA, but must be adequate taking into account all the circumstances. If the parties are unable to achieve an IBA, litigation may very well be the only means by which a developer will know whether consultation was adequate.

IBAs will also become more complex as the level of sophistication of the parties increases. Aboriginal groups are focused on longer term benefits and meaningful opportunities that can sustain generations to come. The question of whether an IBA, once executed, meets the legal obligations set by law will depend on whether the developer has properly assessed the nature of the Aboriginal rights at stake, fully understands the concerns of the Aboriginal groups affected, and in good faith, accommodate these concerns in project planning and responds appropriately where impacts could not be mitigated.

Building meaningful business partnerships may be the best solution to a problem that has no clear answer. 